\title{
Isun Hang Gandrung
}

(Karya tari Tugas Akhir, Pembimbing I \& II: Drs. Gandung Djatmiko, M.Pd dan

Dra. Erlina Pantja S, M.Hum)

Oleh : Elan Fitra Dianto

(Alumnus Jurusan Tari Fakultas Seni Pertunjukan Institut Seni Indonesia Yogyakarta)

\section{RINGKASAN}

Isun Hang Gandrung adalah judul karya tari yang diciptakan. Judul ini sekaligus menjadi konsep dasar yang diwujudkan dalam sebuah koreografi kelompok. Isun dalam bahasa Osing artinya Saya, kemudian Hang berarti yang, dan Gandrung berarti disanjung, dicintai, atau digandrungi. "Isun Hang Gandrung" berarti saya yang digandrungi. Ide tersebut muncul dari ketertarikan terhadap kesenian Gandrung yang dulunya dilakukan oleh laki-laki sehingga disebut Gandrung Lanang.

Gandrung merupakan sebuah kesenian yang berasal dari Banyuwangi, Jawa Timur. Dalam sejarahnya Gandrung dulunya dilakukan oleh seorang laki-laki, namun sekarang berganti menjadi perempuan. Segala bentuk sumber telah dicari melalui buku, wawancara, dan juga melalui video. Hal tersebut sangat membantu dalam proses penciptaan dan penjajakan gerak serta komposisinya.

Karya tari Isun Hang Gandrung disajikan dalam sebuah koreografi kelompok dengan melibatkan delapan penari laki-laki dan satu penari perempuan, dengan menggunakan properti kipas dan dipentaskan di proscenium stage. Gerak yang digunakan bersumber dari gerak tari Gandrung Banyuwangi yang dikomposisikan dengan memperhatikan aspek ruang, waktu, dan tenaga.

Kata kunci : Gandrung, koreografi, Banyuwangi

\section{ABSTRACT}

Isun Hang Gandrung is the title of a dance piece created. The title also became a basic concept that is embodied in a choreography group. Isun in Osing language means „I', Hang means „that"e and Gandrung means praised or loved. "Isun Hang Gandrung "mean that I am loved. The idea came from the interest of the arts Gandrung that formerly done by men so-called Gandrung Lanang.

Gandrung is an art from Banyuwangi, East Java. Historically, Gandrung formerly done by a man, but now turned into woman. All forms of resources have been sought through books, interviews, and also via video. It was very helpful in the process of creation and exploration of movement and composition.

Isun Hang Gandrung dance piece presented in a choreography group involved eight male dancers and one female dancer, the property of the fan was used and staged in a proscenium stage. The motion was obtained from Gandrung Banyuwangi dance composed with attention to aspects of space, time, and energy.

Keywords : Gandrung, Choreography, Banyuwangi 


\section{PENDAHULUAN}

Gandrung merupakan sebuah kesenian rakyat yang hidup dan berkembang di daerah Banyuwangi. Kesenian Gandrung adalah termasuk jenis tari pergaulan, karena di dalam tarian tersebut penari Gandrung selalu menari berpasangan dengan para tamu atau penonton. Tari pergaulan tersebut tidak hanya ada di Banyuwangi, tetapi juga terdapat di daerah Bali dan Jawa yang masing-masing tempat mempunyai nama yang berbeda-beda, seperti : Joged, Gandrung, Taledek, Janggrung, Tayub, dan lain sebagainya.( Sal M. Mugiyanto.t.t. SEBLANG dan GANDRUNG: Dua Bentuk Tari Tradisi di Banyuwangi. Jakarta: Proyek Pembinaan Media Kebudayaan Jakarta. p. 77) Walaupun demikian, Gandrung Banyuwangi memiliki ciri khas tersendiri, yaitu dengan adanya ritual dan sakral yang disebut Seblang.

Pertunjukan Gandrung terbagi atas tiga bagian yakni Jejer, Paju atau Ngibing, dan Seblang Subuh. Jejer merupakan pembuka seluruh pertunjukan Gandrung. Pada bagian ini penari menunjukkan kemampuannya dalam menari, sedangkan para tamu yang umumnya laki-laki hanya menyaksikan. Kemudian setelah jejer selesai, maka penari mulai memberikan selendang kepada tamu untuk menari bersama. Biasanya para tamu terdiri dari empat orang, membentuk bujur sangkar dengan penari Gandrung berada di tengah. Penari akan mendatangi para tamu yang menari dengannya satu persatu dengan gerakan menggoda, dan itulah inti dari tari Gandrung. Setelah selesai, penari akan mendatangi rombongan penonton dan meminta salah satu penonton untuk memilihkan lagu yang akan dinyanyikan. Kegiatan tersebut diselang-seling antara paju dan nyanyi yang akan berlangsung sepanjang malam hingga menjelang subuh. Seblang Subuh, bagian ini merupakan penutup dari seluruh rangkaian pertunjukan Gandrung Banyuwangi. Dimulai dengan ritme gerak yang pelan dan penuh penghayatan sambil menyanyikan lagu-lagu bertema sedih. Suasana mistis terasa pada bagian Seblang Subuh ini, karena masih terhubung erat dengan ritual Seblang.

Menurut sejarah Kesenian Gandrung, awalnya penari Gandrung dilakukan oleh lakilaki, yang berdandan dan berpakaian perempuan sehingga masyarakat menyebutnya Gandrung Lanang. Gandrung Lanang adalah tarian jalanan yang sangat sederhana serta menggunakan alat musik yang sederhana berupa kendang dan rebana. Fungsi Gandrung Lanang saat itu adalah sebagai salah satu strategi perang melawan penjajah. Pada awalnya para penari akan berkeliling desa untuk menggelar pertunjukan Gandrung kemudian mendapat imbalan berupa bahan pangan yang nantinya akan diberikan kepada tawanan penjajah. Selain itu, saat pertunjukan berlangsung para penari menyelipkan seruan untuk menyerang penjajah yang diucapkan dalam bentuk syair lagu. Syair tersebut mengisyaratkan agar bisa menyerang penjajah dengan strategi yang tepat dan mengetahui titik lemah mereka.

Tokoh penari Gandrung Lanang yang terakhir adalah Marsan. Beliau adalah tokoh penari Gandrung Lanang yang terkenal dan tetap menjadi penari Gandrung hingga berumur 40 tahun, sehingga setiap kali ada pertunjukan Gandrung Lanang maka masyarakat menyebutnya Gandrung Marsan. Gandrung menjelang akhir abad ke XIX (k.1.1895) mengalami suatu pembaharuan fundamental.(Soelarko dan S.Ilmi. t.t. Kesenian Rakyat Gandrung dari Banyuwangi. Jakarta:ProyekMedia Kebudayaan Departemen Pendidikan dan Kebudayaan.p.18) Jika pada awalnya Gandrung ditarikan oleh seorang lakilaki yang berdandan dan berpakaian wanita, selanjutnya Gandrung ditarikan oleh perempuan. Selain itu, alat musik yang digunakan tidak hanya kendang dan rebana, tetapi juga penambahan alat musik seperti : biola, kempul, ketuk, kenong, kloneng atau kluncing (triangel). Alasan digantinya penari Gandrung menjadi wanita adalah untuk mengembalikan peran sesungguhnya penari Gandrung yaitu wanita. 
Saat ini kesenian Gandrung hanya menjadi sebuah pertunjukan rakyat yang ditampilkan ketika ada acara tertentu. Berdasarkan wawancara yang dilakukan secara langsung bersama salah seorang penari Gandrung Lanang bernama Subari Sofyan dikediamannya pada hari Rabu, 10 Februari 2016, Gandrung Lanang memiliki keunikan tersendiri yang sangat menarik. Hal ini dikarenakan seorang laki-laki mampu berperan menjadi perempuan, namun tidak melupakan kodratnya sebagai seorang laki-laki. Berdasarkan pengalaman sebagai seniman tari, tidak hanya mampu menarikan tarian laki-laki, tetapi juga dituntut untuk bisa menarikan tarian perempuan. Demikian pula ketika dituntut untuk profesional dalam berkesenian. Ketika diatas panggung dituntut untuk berperan menjadi perempuan, sudah pasti harus menjadi perempuan dan ketika selesai maka kembali ke kodratnya sebagai seorang lai-laki. Menjadi penari tidak harus perempuan saja, laki-laki pun bisa tanpa harus menjadi "melambai" seperti yang ditakutkan para orang tua. Sebagian orang tua merasa takut ketika anaknya masuk kedunia tari, karena ketakutannya akan menjadi gemulai atau banci. Namun, melalui karya tari Isun Hang Gandrung divisualisasikan bahwa menjadi seorang penari tidak akan merubah sikap dan pribadi bahwa pada kodratnya adalah seorang laki-laki.

Karya tari Isun Hang Gandrung disajikan dalam bentuk koreografi kelompok dengan tipe dramatik yang ditarikan oleh delapan penari laki-laki dan satu penari perempuan. Gerak yang digunakan bersumber dari gerak tari Gandrung Banyuwangi. Karya tari ini memvisualisasikan keprofesionalan seorang penari laki-laki yang mampu menarikan perempuan namun tidak melupakan kodratnya sebagai seorang laki-laki. Musik iringan yang digunakan adalah live music agar kesan dramatik lebih terasa dan nuansa yang diinginkan dapat dihadirkan dengan musik iringannya. Busana yang dikenakan adalah busana tari Gandrung dengan sedikit perubahan dibagian rok karena menunjukkan dua karakter penari.

\section{PEMBAHASAN}

\section{A. Rangsang Tari}

Dalam mengawali penciptaan sebuah karya tari biasanya ide muncul karena adanya rangsang. Rangsang inilah yang membangkitkan daya fikir dan mendorong untuk berfikir kreatif sehingga membantu dalam proses penciptaan karya tarinya.

Rangsang yang digunakan dalam proses penciptaan karya tari Isun Hang Gandrung adalah rangsang Visual. Rangsang visual merupakan rangsang yang muncul melalui penglihatan mata secara visual. Rangsang visual yang mendasari penciptaan karya tari Isun Hang Gandrung didapatkan dari melihat pertunjukan karya tari Gandrung Marsan. Kemudian muncul ide untuk menciptakan sebuah karya tari yang bersumber dari Gandrung Lanang yang digarap dalam sebuah koreografi kelompok.

\section{B. Tema}

Tema dalam karya tari Isun Hang Gandrung adalah profesionalisme seorang penari laki-laki yang mampu menarikan perempuan namun tidak melupakan kodratnya sebagai seorang laki-laki. Maksud dari tema tersebut ialah sebagai seorang penari khususnya laki-laki, tidak hanya mampu menarikan tarian laki-laki saja namun juga bisa menarikan tarian perempuan tetapi ketika selesai menari akan kembali kepada kodratnya sebagai seorang laki-laki. Tema yang dipilih dimaksudkan agar dapat memberikan fokus yang jelas terhadap esensi karya yang diciptakan serta dapat menuntun jalannya proses penciptaan.

\section{Judul Tari}

Isun Hang Gandrung dipilih sebagai judul dalam karya tari yang diciptakan. Kata "Isun" berasal dari bahasa Osing yang artinya saya, "Hang" berarti yang, dan "Gandrung" yang berarti di Sanjung atau di cintai. Judul tersebut dipilih karena pada dasarnya penari 
Gandrung sangat dicintai oleh para penikmatnya khususnya masyarakat Banyuwangi. Oleh karena itu, dipilihlah Isun Hang Gandrun sebagai judul dalam karya tari yang diciptakan.

\section{Bentuk dan Cara Ungkap}

Karya tari Isun Hang Gandrung ditampilkan dengan menggunakan tipe dramatik dari gerakan tari Gandrung. Hal tersebut menjadi landasan dari setiap gerakgerak yang digunakan. Tipe dramatik yang dimaksudkan ialah lebih pada penggambaran suasana yang dihadirkan seperti : mistis yakni pada adegan ritual pemakaian omprog yang menggunakan beberapa doa serta properti yang mampu mewujudkan suasana tersebut. Suasana kerakyatan muncul pada adegan berpasangan atau ngibing. Hal ini dikarenakan terdapatnya interaksi antara penari dengan pemusik yang pada kesenian Gandrung adalah hal yang utama. Suasana sedih muncul pada adegan terakhir ketika para penari laki-laki mulai melepaskan omprog dan sampur yang menandakan penyesalan setelah menarikan tarian perempuan dan akhirnya kembali kepada kodratnya sebagai seorang laki-laki.

\section{E. Gerak}

Gerak merupakan elemen dasar dalam aspek koreografi. Karya tari Isun Hang Gandrung berpijak pada gerak tari Gandrung Banyuwangi seperti : miwir, cangkah, sagah, ongkrok, dan liukan badan. Pemilihan gerak dalam karya tari yang diciptakan disesuaikan dengan tema, kemudian dikembangkan dan diolah dengan eksplorasi gerak yang berkaitan dengan aspek ruang, waktu, tenaga, serta permainan level dan arah hadap.

Gerak yang digunakan untuk karakter lakilaki, volume geraknya lebih besar serta gagah. Kemudian untuk karakter perempuan volume geraknya lebih kecil, anggun dan luwes.

\section{F. Penari}

Dalam karya tari yang diciptakan digunakan delapan penari laki-laki dan satu penari perempuan. Alasan digunakan delapan penari laki-laki tersebut ialah sesuai dengan tema dari karya tari yaitu penari laki-laki yang mampu menarikan tarian perempuan, dengan kata lain mampu berperan dalam dua karakter yaitu laki-laki dan perempuan. Dalam hal ini delapan penari terdiri dari satu penari introduksi dan tujuh penari inti. Ketujuh penari inti dapat dimanfaatkan dalam pembuatan pola seperti 4-3, 2-5, 3-2-2, dan lain sebagainya. Selanjutnya dapat juga dalam menentukan fokus penari seperti : focus on one point, focus on two points, dan focus on three points. Kemudian satu penari perempuan dimunculkan pada saat adegan terakhir dengan maksud memvisualisasikan sesuatu hal yang tidak mampu dilakukan oleh seorang laki-laki. Seperti halnya saat persiapan menari untuk laki-laki biasanya telanjang dada, namun untuk penari perempuan akan menggunakan kemben. Dalam karya tari Isun Hang Gandrung penari perempuan dihadirkan untuk mengembalikan peran sesungguhnya penari Gandrung yaitu seorang perempuan.

\section{G. Musik}

Musik merupakan salah satu pendukung dalam sebuah karya tari. Ketika sebuah koreografi belum diiringi musik belum dapat dirasakan sepenuhnya, tetapi ketika hadir bersama-sama dengan iringan musik yang cocok, pertunjukan menjadi lengkap, dan tercapai sentuhan emosionalnya.( Y. Sumandiyo Hadi. 2011. Koreografi Bentuk Teknik Isi.Yogyakarta; Cipta Media.p.115) Musik yang dihadirkan dalam karya tari ini merupakan iringan yang bersifat ilustratif serta untuk mengiringi para penari.

Penggunaan musik dalam karya tari yang diciptakan sangat membantu dalam membangun alur dramatik yang diinginkan. Musik yang digunakan adalah live music dengan menggunakan seperangkat gamelan Banyuwangi seperti : kendang, angklung, triangel, gong, kempul, biola, saron, dan suling serta penambahan beberapa instrumen diluar gamelan Banyuwangi seperti etek-etek, rebana, kenong jawa, suling bali, jirido, cengceng. Penata musiknya ialah Wahyu Tredy 
Pratama salah seorang mahasiswa jurusan Etnomusikologi serta penduduk asli Using Banyuwangi.

\section{H. Rias dan Busana}

Pemilihan rias wajah pada karya ini adalah rias korektif untuk panggung, dalam hal ini digunakan rias cantik.

Dalam pemilihan busana, digunakan busana Gandrung lengkap. Namun, untuk bawahan digunakan bahan yang bisa melar atau elastis. Hal ini dikarenakan adanya perubahan dari kostum laki-laki menjadi perempuan. Sebelum menggunakan kain, penari laki-laki mengenakan celana panji berwarna merah. Selanjutnya terdapat penambahan baju beskap dan ikat kepala Banyuwangi untuk busana laki-laki.

Untuk kostum penari laki-laki yang berubah menjadi kostum perempuan, mirip dengan kostum yang dikenakan oleh penari perempuan. Namun, terdapat beberapa penambahan aksesoris yang digunakan oleh penari laki-laki, yakni : pangkat, kain berwarna hijau, penambahan beberapa rampek, dan kain merah. Untuk penari perempuan menggunakan busana Gandrung pada umumnya.

\section{PEMANGGUNGAN}

\section{Ruang Pentas}

Ruang pementasan menurut penata adalah bagian dari panggung yang dijadikan sebagai tempat untuk menari. Tempat pertunjukan dalam karya tari Isun Hang Gandrung berada di proscenium stage. Alasan digunakannya proscenium stage yaitu adanya backdrop yang digunakan dalam salah satu adegan. Selain itu, dengan adanya side wing membantu dalam keluar masuknya penari.

\section{Lokasi Pementasan}

Area lokasi pemetasan sebuah pertunjukan harus strategis, karena dapat berpengaruh dengan apresiasi penonton yang datang. Lokasi pementasan berada didalam ruangan yaitu di Auditorium jurusan tari Institut Seni Indonesia Yogyakarta.

\section{Tata Rupa Pentas}

Dalam karya tari ini, penata tari menggunakan properti berupa kipas, nampan untuk alas dari omprog, dupa, dan bunga. Dupa dan bunga berfungsi sebagai perlengkapan dalam adegan ritual. Selanjutnya kain hitam dan putih sebagai penutup omprog saat dibawa oleh penari pada adegan introduksi, sedangkan kain putih digunakan sebagai penutup omprog pada adegan ritual pemakaian omprog.

Setting yang digunakan ialah level berukuran $2 \times 1$ berjumlah empat dan ukuran 1x1 berjumlah satu. Level tersebut digunakan pada saat adegan ritual pemakaian omprog dan pembacaan mantra yang berada dibelakang panggung.

\section{Tata Cahaya}

Tata cahaya yang digunakan dalam karya tari Isun Hang Gandrung lebih bersifat pencahayaan. Tata cahaya bisa membantu menunjukkan suasana serta emosi dalam setiap adegan dalam karya tari ini. Terdapat beberapa fokus lampu yang digunakan pada beberapa adegan yang membutuhkan lampu tambahan. Seperti misal : penggunaan tata cahaya yang digunakan dibelakang backdrop tepatnya di antara pintu keluar belakang panggung yang digunakan untuk adegan ritual.

\section{EVALUASI}

Dalam tahap realisasi proses dan hasil penciptaan karya, penata tari membagi karya dalam beberapa adegan atau segmen, yaitu :

\section{a. Introduksi}

Introduksi merupakan adegan yang pertama kali dilihat oleh penonton. Introduksi biasanya berisi tentang apa yang ingin disampaikan, asal mula objek atau ringkasan cerita yang ingin dihadirkan. Dalam karya tari Isun Hang Gandrung, introduksi menceritakan awal mula penari Gandrung. Penari Gandrung dulunya adalah seorang laki-laki yang berpakaian dan berdandan seperti perempuan. Dalam adegan ini terdapat seorang penari yang 
naik ke panggung dengan membawa omprog dan tiga orang penari dengan maksud mempersiapkan diri untuk berdandan. Seperti halnya penari jika akan pentas, maka hal pertama yang dilakukan adalah berias diri.

Berikutnya muncul lagi lima penari dengan gerak yang keras dan tegas. Hal tersebut menggambarkan para laki-laki yang gagah dan akan bersiap menjadi penari Gandrung. Selanjutnya para penari menuju ke kiri panggung dengan gerak yang pelan dan terkomposisikan sampai akhirnya berjalan menuju backdrop untuk bersiap-siap untuk ritual pemakaian omprog.

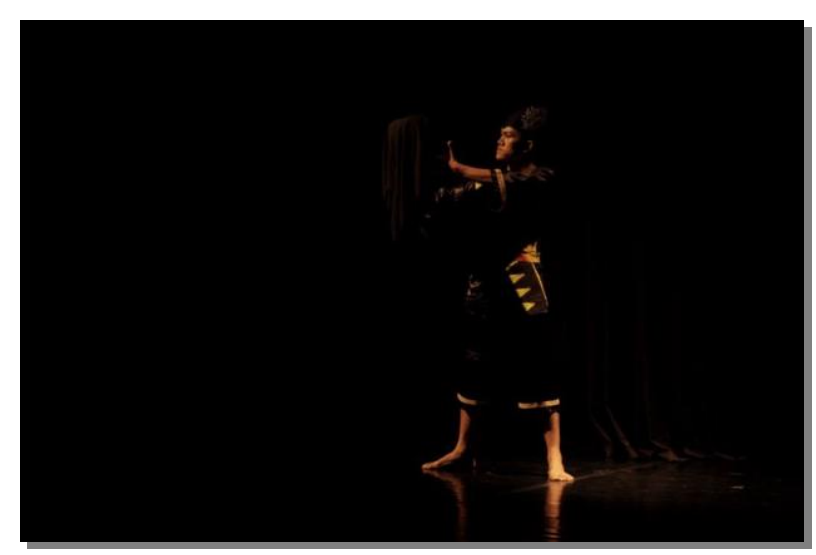

Gambar 1. Salah seorang penari dengan membawa omprog pada adegan introduksi (dok. Ikeldiyo Art, 2016)

\section{b. Adegan 1}

Adegan 1 dimulai dengan adanya ritual pemakaian omprog. Omprog merupakan mahkota yang wajib digunakan oleh penari Gandrung. Dalam nyatanya, setiap penari Gandrung memiliki ritualnya masing-masing dalam memakai omprog. Adegan 1 ini ritual pemakaian omprog dilakukan oleh dua orang penari yang berada dibelakang bakcdrop. Kedua penari melakukan gerakan doa terlebih dahulu dengan terdapat sesaji dan omprog pastinya. Adegan 1 ini pada dasarnya merupakan jejeran atau memperlihatkan kemampuan penari Gandrung. Dalam hal ini para penari laki-laki menarikan tari perempuan dan berperan sebagai perempuan.

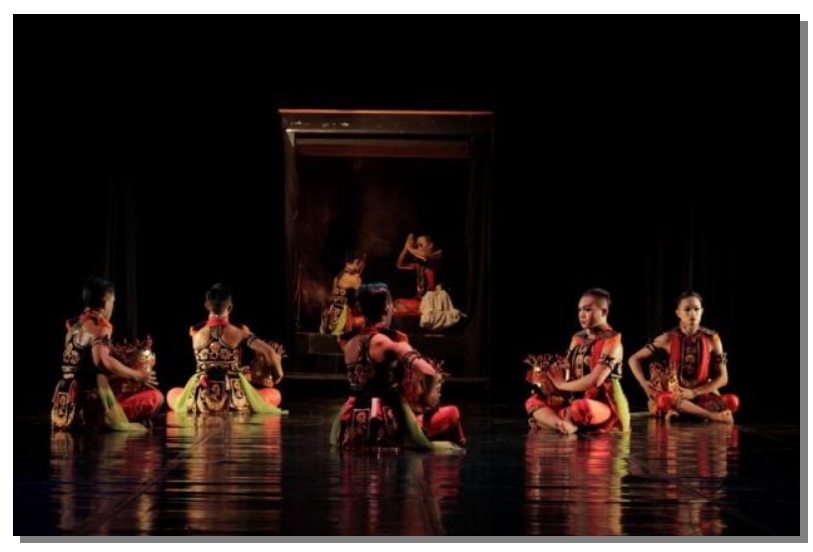

Gambar 2. Adegan ritual pemakaian omprog (dok. Ikeldiyo Art, 2016)

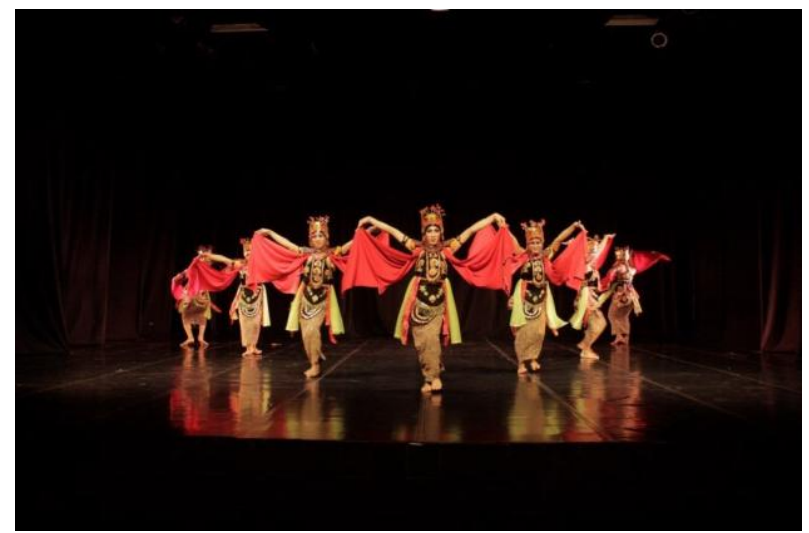

Gambar 3. Adegan satu yaitu adegan jejeran ( dok. Ikeldiyo Art, 2016 )

\section{c. Adegan 2}

Adegan 2 dimulai dengan satu penari menari sendiri yang masih berperan sebagai perempuan. Adegan dua merupakan adegan Paju Gandrung yaitu inti dari kesenian Gandrung yang juga merupakan fokus utama dalam garapan tari Isun Hang Gandrung. Dalam adegan ini diperlihatkan para penari laki-laki yang mampu menarikan tarian lakilaki dan perempuan. Terdapat adegan ngibing atau berpasangan antara laki-laki dan perempuan. Selain itu, terdapat fokus pasangan yaitu Dwi Purnama dan Tri Anggoro yang menari dengan iringan musik yang bernuansa nuansa Dangdut. Interaksi antara penari dan pemusik juga terjalin dalam adegan dua ini, seperti contoh ketika salah seorang penari meminta iringan musik yang sedikit 
lepas dari Banyuwangi yaitu Dangdut, contoh ucapan yang dilontarkan ialah, " Cak, mandheg-mandheg, riko iki iso kendangi isun ga ta Cak, kendangi seng penak tak njoget ". Setelah selesai adegan ngibing penari yang berperan sebagai perempuan keluar dan tersisa penari laki-laki dan masuk dalam adegan tiga.

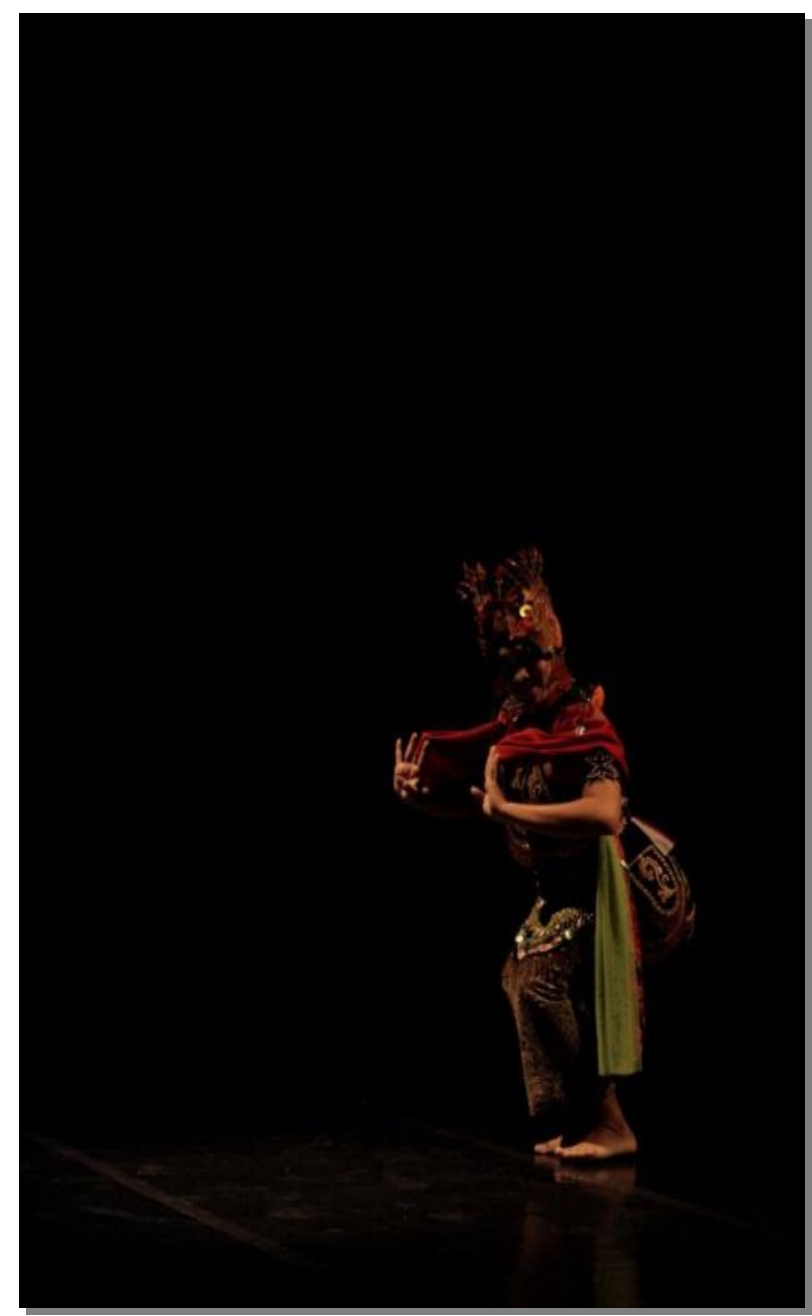

Gambar 4. Adegan tunggal penari Gandrung dalam adegan dua atau paju Gandrung ( dok. Ikeldiyo Art, 2016 )

\section{d. Adegan 3}

Setelah penari yang berperan sebagai perempuan keluar panggung, tinggal para penari laki-laki. Penari melakukan gerak yang lebih maskulin dengan volume yang besar dan tegas. Setelah itu terdapat sedikit peralihan ke gerak yang perempuan, kemudian black out dan penari keluar.

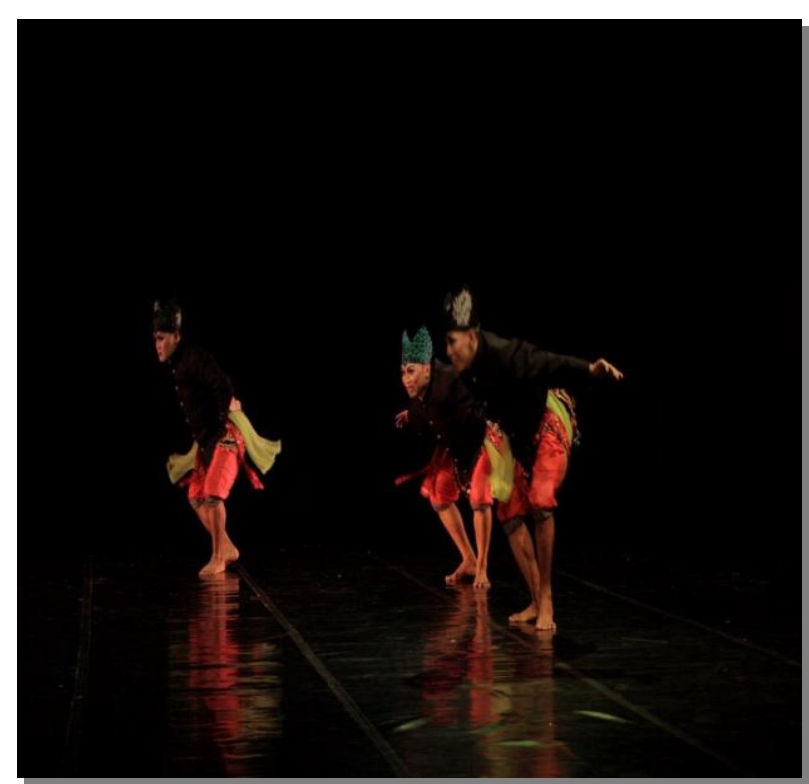

Gambar 5. Adegan penari laki-laki yang masuk dalam adegan ketiga ( dok. Ikeldiyo Art, 2016 )

\section{e. Ending}

Dalam adegan terakhir karya tari Isun Hang Gandrung, diwujudkan dengan munculnya penari perempuan yang menari di belakang backdrop dengan menggunakan kipas. Kemudian disusul oleh tujuh penari laki-laki dari belakang backdrop juga secara bersamaan. Gerak yang dilakukan sama dengan volume yang sama pula. Selanjutnya penari perempuan menari kedepan hingga apron sedangkan penari laki-laki mundur ke dead centre. Penari perempuan melakukan gerak miwir dengan pelan dan anggun, kemudian menuju ke down stage right. Di sisi lain penari laki-laki melakukan gerak megol miring menuju up stage left dan dilanjutkan dengan gerak lepas omprog sampai front curtain ditutup dan pertunjukan selesai.

Adegan ending ini merupakan puncak dari apa yang ingin disampaikan oleh penta tari yakni sepandai-pandainya seorang lakilaki menarikan tarian perempuan, terdapat kodrat yang tidak bisa dilawan. Kodrat yang sesungguhnya adalah seorang laki-laki, dan semua yang dilakukan diatas panggung hanyalah sebuah profesionalisme semata. 


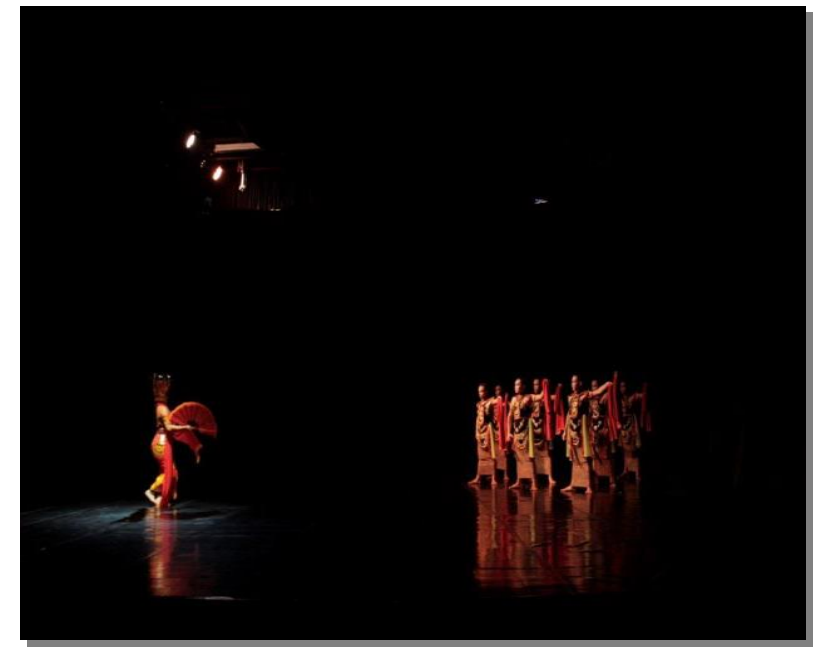

Gambar 6. Adegan terakhir ketika penari lakilaki melepas sampur dan melihat ke arah penari perempuan ( dok. Ikeldiyo Art, 2016 )

\section{KESIMPULAN}

Karya tari Isun Hang Gandrung merupakan sebuah karya tari yang terinspirasi oleh kesenian Gandrung Banyuwangi khususnya Gandrung Marsan. Gerak miwir, cangkah, sagah, ongkrok, dan liukan badan merupakan fokus gerak dalam garapan karya tari Isun Hang Gandrung. Ketertarikan dalam penciptaan karya tari ini dimulai ketika penata tari melihat karya tari Gandrung Marsan dalam festival tari Nusantara tahun 2009 di Jakarta. Oleh sebab itu muncul sebuah rangsang visual untuk menciptakan sebuah karya tari yang bersumber dari Gandrung Marsan dengan spesifikasi penari dapat dan mampu menarikan tari perempuan dan juga laki-laki. Hal tersebut juga didukung dengan adanya mata kuliah koreografi dan kelas pendukung lainnya sehingga membantu penata tari dalam menciptakan karya tari.

Karya tari Isun Hang Gandrung merupakan sebuah komposisi tari kelompok dengan delapan penari laki-laki dan satu penari perempuan. Dalam penyajiannya karya tari Isun Hang Gandrung terbagi dalam lima adegan yakni introduksi, adegan I II III, dan ending dengan pola garap menggunakan tipe dramatik. Penggunaan setting dalam karya tari
Isun Hang Gandrung tidak terlalu rumit hanya menggunakan level berukuran 2x1 berjumlah empat dan 1x1 berjumlah satu yang diletakkan belakang panggung.

Karya tari Isun Hang Gandrung diharapkan mampu untuk memberikan pengalaman visual kepada para penonton bahwa Gandrung Lanang memiliki suatu keindahan dan nilai artistik yang tinggi sebagai sebuah karya seni. Materi gerak yang disampaikan melalui karya tari ini merupakan hasil pengamatan dan intrepetasi dari motif gandrung yang telah mendapatkan pengembangan dengan memperhatikan konsep koreografi. Karya tari Isun Hang Gandrung juga diharapkan dapat memberikan pemahaman kepada penonton tentang maksud dari seorang laki-laki yang berperan sebagai perempuan dalam konteks sebuah pertunjukan tari.

\section{DAFTAR SUMBER ACUAN}

\section{A. Sumber Tertulis}

Ali, Hasan. 2004. Kamus Bahasa Daerah Using-Indonesia. Banyuwangi : Pemerintah Daerah Kabupaten Banyuwangi.

Dariharto. 2009. Kesenian Gandrung Banyuwangi. Banyuwangi : Dinas Kebudayaan dan Pariwisata Kabupaten Banyuwangi.

Dibia, I Wayan, FX. Widaryanto, Endo Suanda. 2006. Tari Komunal. Jakarta : Lembaga Pendidikan Seni Nusantara.

Griffiths Trevor R. 1998. Stagecraft : The Complete Guide Theatrical Practice. New York : Knickerbocker Press.

Hadi, Y. Sumandiyo. 2003. Aspek-aspek koreografi kelompok. Yogyakarta: Elkaphi. 
2011. Koreografi : BentukTeknik-Isi. Yogyakarta : Cipta Media.

Haryamawan, RMA. 1988. Dramaturgi. Bandung : Rosda Offset.

Martono, Hendro. 2008. Sekelumit Ruang Pentas : Modern dan Tradisi. Yogyakarta : Cipta Media.

2010. Mengenal Tata Cahaya Seni Pertunjukan. Yogyakarta : Cipta Media.

Murgiyanto, Sal M. T.T. Seblang dan Gandrung : Dua Bentuk Tari Tradisi di Banyuwangi. Jakarta : Media Kebudayaan.

M. Echols, John, Hassan Shadily. 1998. Kamus Inggris Indonesia. Jakarta : PT. Gramedia Pustaka Utama.

Padmodarmaya, Pramana. 1998. Tata dan Teknik Pentas. Jakarta : Balai Pustaka.

Santoso, Tri Budi. 2009. Skripsi Tugas Akhir Tari : Fungsi Seblang Bagi Masyarakat Osing di Desa Olehsari Kecamatan Glagah Kabupaten Banyuwangi. Yogyakarta : Perpustakaan Institut Seni Indonesia Yogyakarta.

Smith, Jacqueline. 1976. Dance Composition: A Practical Guide For Teachers. London : Lepus Book, terj. Oleh Ben Suharto. 1985. Komposisi Tari

Sebuah Petunjuk Praktis Bagi Guru. Yogyakarta : Ikalasti.

Soelarko, B, S. Ilmi. t.t. Kesenian Rakyat dari Banyuwangi. Jakarta : Proyek Pengembangan Media Kebudayaan. Departemen Pendidikan dan Kebudayaan.
Sumaryono, Endo Suanda. 2006. Tari Tontonan. Jakarta : Lembaga Pendidikan Seni Nusantara.

Wijaya, Arie Yulia. 2011. Skripsi Tugas Akhir Seni Tari : Analisis Struktural Gandrung Terob Banyuwangi. Yogyakarta : Perpustakaan Institut Seni Indonesia Yogyakarta.

\section{B. Sumber Video}

- Video tari Gandrung Marsan karya Subari Sufyan

- Video tari Gandrung Banyuwangi

- Video tari Gemblak karya Mamuk Rohmadona

\section{Sumber Lisan}

Nama : Subari Sofyan

Umur : 59 tahun

Pekerjaan : penata tari, penari Gandrung Lanang, perias busana, dan pemilik sanggar "Sayu Gringsing"

Nama : Ammy Aulia Renata

Usia : 21 tahun

Pekerjaan : Penari Gandrung dan Alumni ISI Yogyakarta. 
